\title{
Factors associated with the occurrence of dengue epidemics in Brazil: a systematic review
}

\author{
Selma Costa de Sousa, ${ }^{1}$ Mariângela Carneiro, ${ }^{1}$ Álvaro Eduardo Eiras, ${ }^{1}$ Juliana Maria Trindade \\ Bezerra $^{2}$ and David Soeiro Barbosa ${ }^{1}$
}

Suggested citation Sousa SC, Carneiro M, Eiras AE, Bezerra JMT, Barbosa DS. Factors associated with the occurrence of dengue epidemics in Brazil: a systematic review. Rev Panam Salud Publica. 2021;45:e84. https://doi.org/10.26633/RPSP.2021.84

ABSTRACT Objective. To identify and describe broadly the factors related to the occurrence of dengue epidemics in Brazil.

Methods. Systematic review of studies published in Medline, Lilacs, PubMed, Cochrane, BVS, Web of Science, Scopus, and thesis and dissertations databases using descriptors cataloged in DeCs and MeSH on dengue and factors associated with the occurrence of epidemics, published from 2008 to 2018.

Results. Thirty-five studies carried out in the country were selected. The epidemics recorded in Brazil were associated and/or correlated with multiple factors such as environment, socioeconomic conditions, climate, and aspects related to the vector, among others.

Conclusions. Dengue epidemics are complex and multifactorial. The continuity of the vector control actions was found to be relevant to the reduction of Aedes aegypti and for disease control. To contain the spread of the disease, effective measures are needed in all sectors, including health, education, economy, population, business, and government. Actions for the early detection of cases of the disease can prevent new outbreaks of epidemics.

Keywords Dengue; risk factors; epidemics; Brazil.

Since the report of the first dengue epidemic in Brazil (1), the country has been presenting successive epidemics and uninterrupted expansion of the disease (2). As of 2008, a concomitant circulation of the four serotypes of the dengue virus (DENV) was observed in the five Brazilian regions, due to the reintroduction of DENV-4 after almost 30 years without being identified (3). Additionally, the vectors Aedes aegypti $(4,5)$, the main transmitter in urban areas, and Ae. albopictus are present in suburban and peri-urban areas of the country $(3,4)$.

An important public health problem, dengue creates a social and economic burden for endemic countries (6). Brazil was responsible for $65 \%$ of the dengue cases reported in the Americas between 2014 and 2019 (5). In addition, a 266.1\% increase in the rate of disability-adjusted life years per 100000 inhabitants was observed between 2000 and 2015 (7).

Several factors have been related to the spread of the disease and the vector in the country, such as population growth, migration, air travel, inadequate urbanization, malfunctioning health systems, population density, and socioeconomic inequalities, among others (8). In addition to the increasing number of cases of the disease, the increase in reports of severe forms in the last decades may be related to the concomitant circulation of different serotypes of the virus, as well as the virulence of the circulating strains (9).

Considering the current scenario of dengue in Brazil, we aimed to identify and describe broadly the factors related to the

\footnotetext{
1 Universidade Federal de Minas Gerais, Belo Horizonte, Brazil $₫$ David Soeiro Barbosa, davidsoeiro@icb.ufmg.br
}

2 Universidade Estadual do Maranhão, Lago da Pedra, Brazil

This is an open access article distributed under the terms of the Creative Commons Attribution-NonCommercial-NoDerivs 3.0 IGO License, which permits use, distribution, and reproduction in any medium, provided the original work is properly cited. No modifications or commercial use of this article are permitted. In any reproduction of this article there should not be any suggestion that PAHO or this article endorse any specific organization
or products. The use of the PAHO logo is not permitted. This notice should be preserved along with the article's original URL. Open access logo and text by PLoS, under the Creative Commons Attribution-Share Alike 3.0 Unported license. 
occurrence of dengue epidemics in Brazil in order to contribute to the better understanding of the dynamics of the epidemics in different scenarios.

\section{METHODS}

A systematic review was carried out on the determinants for the occurrence of epidemics and/or outbreaks of dengue in Brazil from 2008 to 2018.

\section{Study design}

The research was carried out in different electronic scientific databases, using descriptors related to the factors associated with dengue in Brazil. The studies were identified and included in the first semester of 2018.

This study was registered in the International Prospective Register of Systematic Reviews (PROSPERO, 2018) under the registration number CRD42018095019 and followed the recommendations of the Preferred Reporting Items for Systematic Reviews and Meta-Analyzes (PRISMA, 2015).

\section{Elegibility criteria}

Studies that measured the association and/or correlation of specific factors with dengue epidemics and/or outbreaks, published in Brazil between 2008 and 2018, in English, Portuguese or Spanish were included in the systematic review. The searches were conducted in March 2018.

Studies carried out within the Brazilian territory, as well as epidemiological studies that describe the association between the occurrence epidemic and/or dengue outbreak and social, economic and environmental variables were included. Case series studies, studies restricted to the description of cases or variables and studies with bias or inconsistencies were excluded.

\section{Databases}

The bibliographic search was carried out in the following electronic databases: Medline, Lilacs, PubMed, Cochrane, VHL, Web of Science, Scopus and Library of Theses and Dissertations from Coordination for the Improvement of Higher Education Personnel-CAPES/Brazil.

\section{Search strategy}

The searches were conducted using the descriptors cataloged in the Health Sciences Descriptors (DeCS) and Medical Subject Headings (MeSH), in Portuguese, English, and Spanish, found in the title or in the study abstracts. The boolean operators "AND" and "OR" were used for a more specific search in the titles.

The following search terms were used in the databases: Group 1: Dengue/Dengue Virus/Aedes; Group 2: Disease Outbreaks/Epidemics; and Group 3: Epidemiology. To characterize the demographic, environmental, and socioeconomic variables, the following groups of descriptors were used: (1) risk factors; (2) life style; (3) urban; (4) social and economic conditions, and (5) cultural characteristics. The bibliographic search was assisted by a professional librarian at the Universidade Federal de Minas Gerais, tested and reproduced by two researchers.

\section{RESULTS}

\section{Analysis of studies}

Initially, 4445 studies were systematically selected in the bibliographic search. Of these, 1148 were excluded due to duplication and after reading the titles/abstracts (3 159). Then, 103 studies were excluded after reading the full text, remaining 35 included studies (Figure 1). Two independent reviewers examined the titles and abstracts of all manuscripts that met the inclusion criteria. The selected titles were read in full and additional studies were excluded. When the two reviewers did not agree to the exclusion of a study, a third reviewer was asked to read the title and help with the decision. Manuscripts that did not answer the text question, which were not related to the study question (dengue epidemic) and other languages (except English and Spanish and Portuguese) were excluded.

Thirty-five studies complied with the eligibility criteria and were included in the systematic review. Most of them were conducted in the Southeast region of Brazil $(\mathrm{N}=22)$, followed by the Northeast $(\mathrm{N}=6)$, North $(\mathrm{N}=3)$, Central-West $(\mathrm{N}=1)$, and South $(\mathrm{N}=2)$. In addition, one study was carried out in the whole country $(\mathrm{N}=1)$ (Table 1 and Figure 2). Six studies were published in 2010 , six in 2015, five in 2017, three in 2008, three in 2011, and four in 2014. The years 2009, 2012, 2013, and 2016 had two publications each. Meteorological and climatic variables were described as related to the dengue epidemic 17 times, followed by the variables related to the vector (12 times), and the socioeconomic and variable related to environmental factor environmental factors (eight times each). Also, we found other associations between dengue and other factors in four studies (Figure 3).

\section{Variables related to the vector}

The incidence of dengue was associated or correlated with the amount of eggs collected in ovitramps $(10,11)$ and the entomological indices: Building Infestation Index (IIP) (10-12), Breteau Index (IB) (13-15), Container Index (IR) (16,17), Larvae Index (IL) (17), Pupae per property (PP) (17), and Pupae per hectare (PH) (17).

FIGURE 1. Flowchart of the selection of studies on the factors associated with the occurrence of dengue epidemics in Brazil

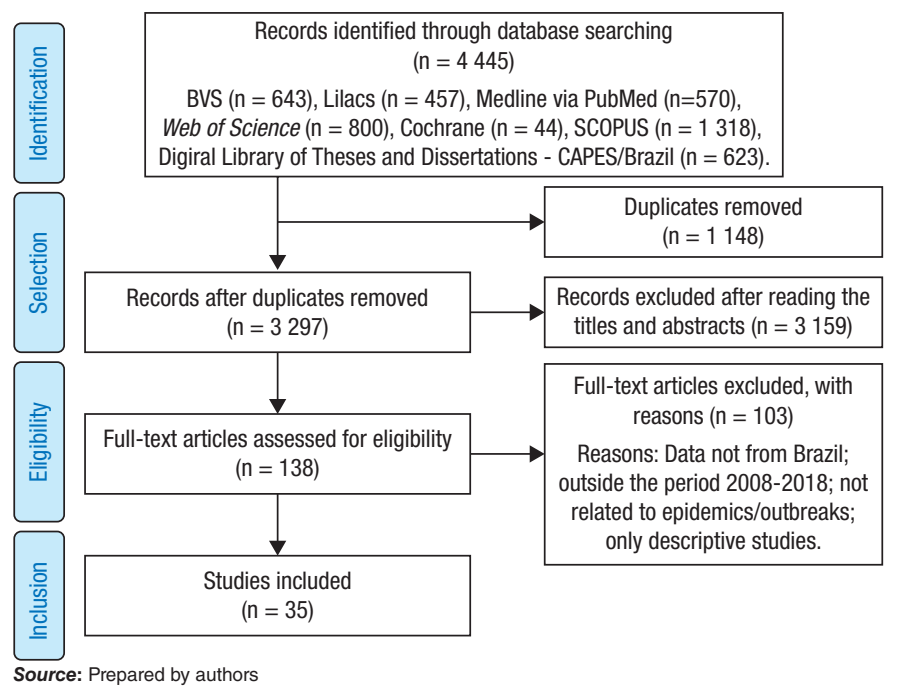


TABLE 1. Chronological categorization of the studies on the factors associated with the occurrence of dengue epidemics in Brazil published between 2008 and 2018, according to the geographic area and type of factor

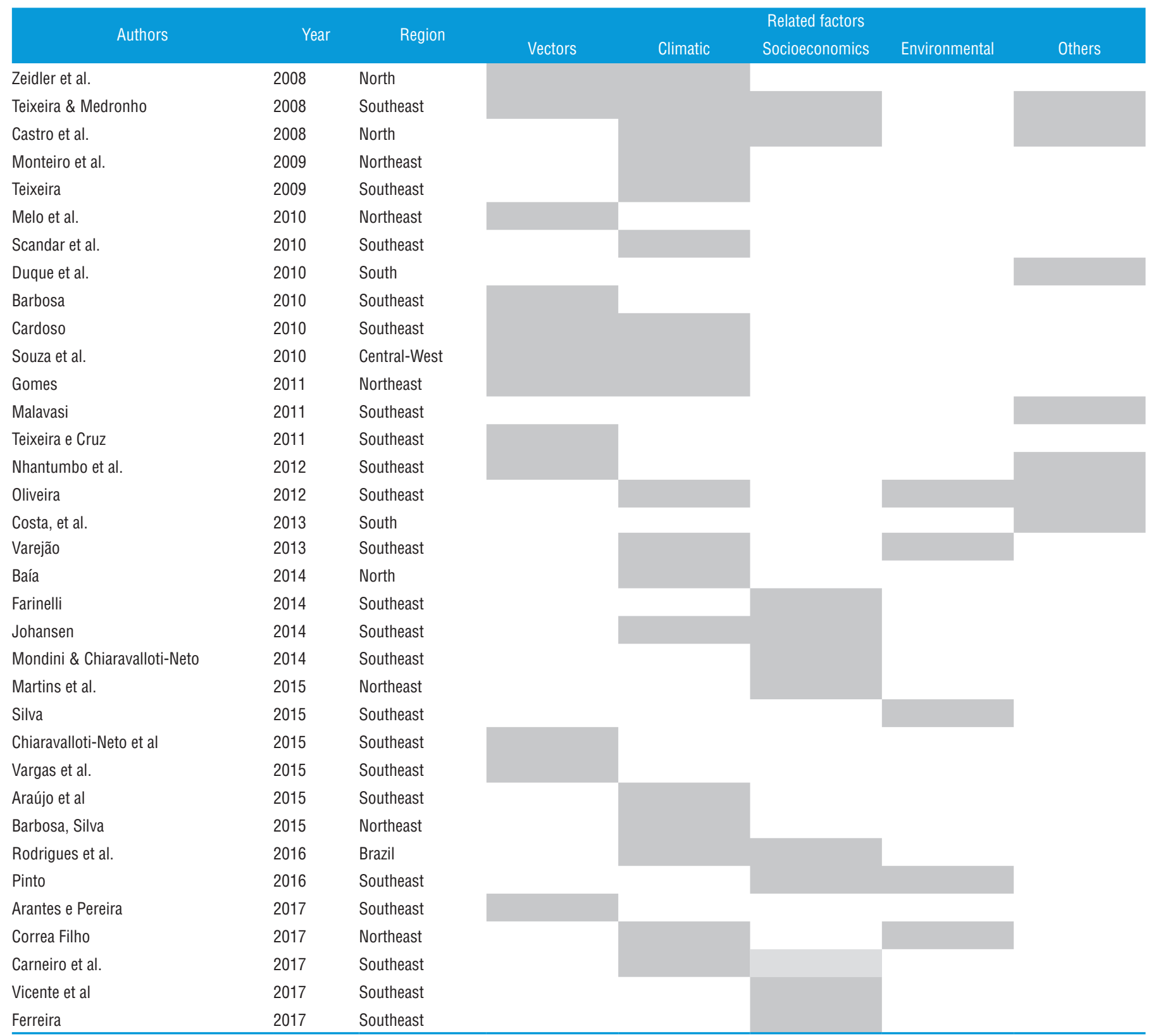

Source: Prepared by authors

Two studies evaluated the number of eggs found in strata and the incidence of dengue and showed correlation to the findings of eggs in the neighborhoods (10) and evaluated districts (11). The number of eggs deposited by Ae. aegypti in ovitramps negatively correlated with the incidence rate of dengue cases in a state in the North region of Brazil (10). In the Southeast, a greater risk of dengue incidence was found in locations that had more than 20 eggs per strata analyzed (16).

A negative and weak association $(6,14)$ and a positive and weak correlation (10) among the incidence of dengue and IB for Ae. aegypti, and positive and weak association for Ae. albopictus $(8,18)$ were found in three studies. The IIP has been positively correlated with the incidence of dengue in several studies $(6,11,12,14,18,19)$. There was also a positive and significant correlation between the incidence of dengue and IL grouped by month and considering two months of lag in two epidemic years studied (17). The IR was another indicator that showed a significant positive correlation with the incidence of dengue (16).

One of the selected studies also used the indicators from the World Health Organization (WHO) Força Motriz-PressãoEstado-Exposição-Efeito/Ação (FPEEA) adapted for the analysis of the occurrence of dengue and showed a positive correlation between the Rapid Index Survey for Ae. aegypti (LIRAa) with the average number of dengue cases (13). 


\section{Climatic or meteorological variables}

More than half of the studies showed an association or positive correlation between climatic and/or meteorological variables and the dengue incidence. Precipitation $(6,10,12,14,18,20-24)$,

FIGURE 2. Distribution of the studies published between 2008 and 2018 on factors associated with the occurrence of dengue epidemics in Brazil, according to the geographical area of study

Published scientific studies $(\mathrm{N}=35)$

$\checkmark$ Federated units
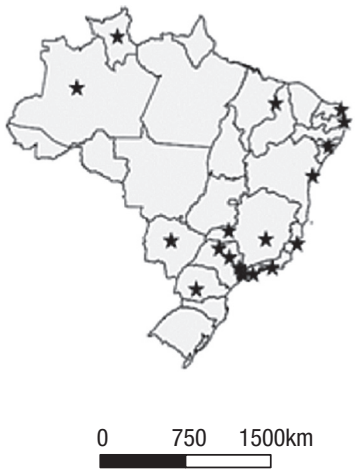

was the predominant factor, followed by temperature $(12,16,20,24-28)$, relative air humidity $(24,29)$, wind direction and speed (24), and average sunspots per month (16).

There was a strong positive correlation between precipitation and the number of dengue cases (12), the incidence rates $(15,23)$, and dengue epidemics $(18,20,21)$. Rainfall accounted for only $13.2 \%$ of the variation in dengue incidence rates in one study (22).

In a GLM model, a direct association was observed between the incidence of dengue and rainfall and the time lag of a month of rainfall. CAR spatial model for each month, revealed that the incidence of dengue was directly associated with the rainfall in January, March, May, and June, and with the time-lag of rainfall in July (5).

The variables temperature (25); mean temperature without lag and with a lag of one, two, or three months (16); high temperature (26); maximum temperature (27); monthly average and monthly minimum temperature measured at 9 am, 3 pm, and 9 pm (16); sea surface temperature (34); minimum temperature (20); air temperature (24); and land surface temperature above $32{ }^{\circ} \mathrm{C}(28)$ were correlated and positively associated with the number of dengue cases in different regions of the country. In one study, the minimum temperature showed a weak and negative correlation with the notifications of the disease (27).

The variables dew-point temperature (27); wind direction (24); solar cycles (30); and wind flow (20) were also positively

Source: Prepared by authors

FIGURE 3. Positive and negative correlations/association to the occurrence of dengue epidemics verified in the studies published on the factors associated with the occurrence of dengue epidemics in Brazil between 2008 and 2018

Positive

Proximity to the risk point: 2

Case distribution: 1

Proximity to parks: 1

Existence of highways: 1

Existence of marginal roads: 1

Number of neighbors: 1

Urban area: 2

Living far from urban area: 1

Percentage of residents per household: 1

Existence of particulate material

of industries in the air: 1

Living far from urban area: 1

Positive

Income: 6

GINI Index: 2

Population in households with bathroom

and running water: 5

Garbage collection: 1

Human development index

by municipality: 1

Number of residents per household and number of individual household: 1

Population growth rate: 1

Proportion of vacante lots in relation to

total properties: 1

Resident person, black and brown

race/skin color: 1

Negative
Proportion of poor: 2

Literacy (conversely): 1
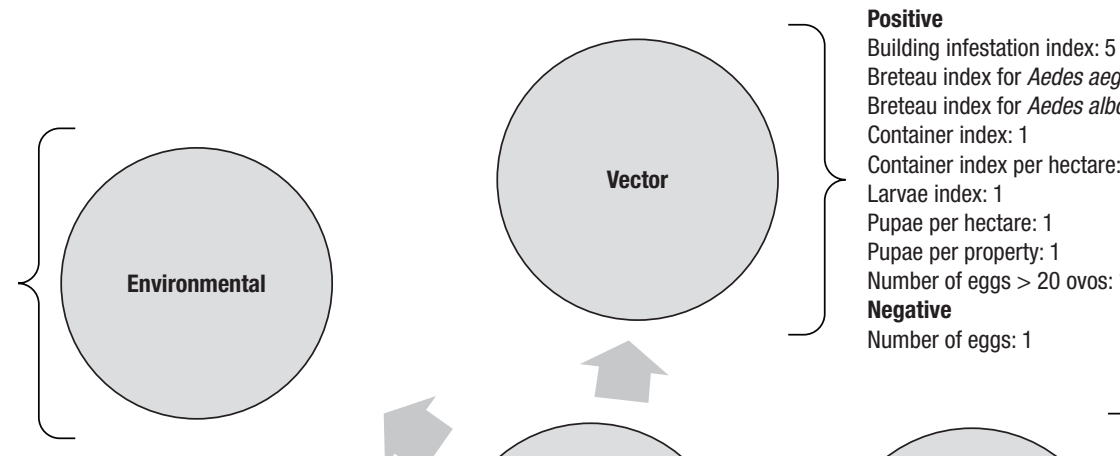

Breteau index for Aedes aegpyti: 3

Breteau index for Aedes albopictus: 1

Container index: 1

Container index per hectare: 1

$\succ$ Larvae index: 1

Pupae per hectare: 1

Pupae per property: 1

Number of eggs $>20$ ovos: 1

Negative

Number of eggs: 1

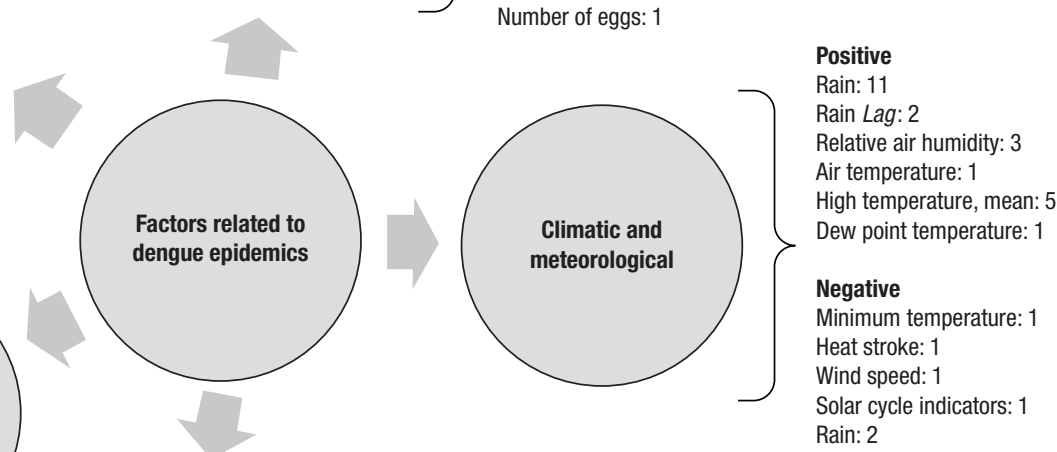

Note: The numbers for each factor correspond to the number of studies that presented the positive or negative correlations described. More detailed information is available from the authors upon request. Source: Prepared by authors 
correlated with the incidence of dengue in epidemic years. In addition, the humid climate without a dry season and with a rainy season in the summer; the humid climate without a dry season and with a rainy season in the summer and dry winter; the hot summer with no dry season; and the mild summer with no dry season showed an association with the occurrence of dengue in a study conducted in Brazil (30). The variable relative humidity correlated with dengue epidemics in three studies $(20,24,29)$.

\section{Socioeconomic factors}

Many factors were considered including population density and income (31), population growth rate (22), proportion of people living in poverty (21), a lower per capita income (21), a lower proportion of the population in households with bathrooms and running water $(21)$, Gini index $(6,30)$, population with access to piped water, proportion of permanent private households with garbage collection (32), number of literate people responsible for the household (33), human development index (34), gross domestic product (30), and proportion of vacant lots on the total number of properties (22).

Several authors pointed out the small proportion of properties with running water (32), the smaller proportion of the population in households with bathrooms with running water (21), the proportion of permanent private households with garbage collection $(35,36)$, the residents in permanent private households with a general water distribution system (37), and the permanent private households with garbage collection by cleaning service, and water supply from the general network as variables associated or correlated with the incidence of dengue (37).

Income was identified as a predictor of the incidence of dengue when assessed by the Gini index $(6,30)$. In studies conducted in different Brazilian regions that evaluated the variables related to lower per capita income $(21,31)$, income (27), monthly income of 1 to 2 wages $(27,37)$, residents with 3 to 5 minimum wages (27), and proportion of individual houses (27), individuals were most affected by the dengue epidemic.

The literacy rate was also associated or correlated with the incidence of dengue. The analyzed variables were literate people aged five years or older (37), literate responsible (21), illiterate chief (37), and illiterate people (37). In another study, the variable literate person responsible for the household showed a negative association with the incidence of dengue (35).

In one study, poverty was positively associated with the incidence of dengue (21). There was also a positive and significant correlation between the Municipal Human Development Index and the number of dengue cases (21). Only one study identified a correlation between the variable black and brown color/race and the incidence of dengue (37).

\section{Variables related to environmental factors}

The environmental variables strategic point; proximity to parks and urban areas (24), existence of highways and marginal roads (38), presence of type A2 (13) deposits, and presence of particulate material (PM10) released by industries (29) were evaluated.
In two studies, houses close to risk points or strategic points showed an important role in the dispersion of the vector mosquito, thus influencing the speed of the spreading of the transmission right after it is installed $(39,40)$. The variables proximity to parks and urban areas (20), shorter distance between urban centers and municipalities (26), existence of highways, and existence of marginal roads in the districts (38) showed a significant association or correlation with the dengue epidemics.

\section{Other factors}

The organization of surveillance and health care services was also identified as predictor of dengue epidemics in the country. The period of diagnosis and the registers of the disease were variables associated with the incidence of dengue (25). In addition, the adequate ratio of the number of agents and field supervisors who did not reach the stipulated target of visits was associated with the dengue epidemic in one study (21). The percentage of coverage of the teams of the Family Health Program (Programa de Saúde da Família) showed a negative correlation with the dengue epidemic in another study (15). Intervention indicators such as pending actions in dengue vector control programs were also positively associated with dengue transmission in 10 to $24.9 \%$ (15). There was also a positive correlation between dengue epidemics and the ratio between the distance from the first detected dengue case and the number of neighbors (39) and the variables areas of boundary and borders with Brazil in two Brazilian states (Maranhão and São Paulo) and one country (Paraguay) (41).

\section{DISCUSSION}

We analyzed publications available in different scientific electronic databases for the years 2008 to 2018. Among the factors related to dengue epidemics, the climatic or meteorological factors stood out in 17 studies. In addition, related variables socioeconomic, environmental, and other factors also stood out. To the best of our knowledge, this is the first study to present a broad description of the factors involved in dengue epidemics in Brazil.

Indicators such as IIP, IB, and ITR were addressed by several authors $(6,11,12,15,32,42)$, who mostly found them related with dengue epidemics. Few studies showed a positive but weak correlation between larval indicators and the incidence of dengue $(6,14,16)$. Other studies presented a strong positive correlation $(13,17)$, suggesting that these larval indicators have the potential to describe the behavior of dengue in the years studied.

Studies that assess the pupal stage are more likely to be accurate in understanding the biology of Ae. aegypti when compared to studies with larvae. The duration of a pupa is about 2 days depending on the temperature (3), so these studies are more difficult to be performed. Therefore, studies with pupae can provide more adequate responses for the control of the vector and the reduction of arboviruses.

The mortality rate of pupae is almost zero. Pupae become adult individuals, unlike the larvae, which are influenced by the temperature of the environment, the volume of water, the amount of food present in the container and, therefore, have a higher mortality rate $(4,43)$. Corroborating this finding, a study carried out 
in 2014 in São José do Rio Preto (Sao Paulo), showed that pupal indicators were positively associated with the incidence of dengue (42). Prioritizing the finding of immature forms of the vector at strategic points or points of risk has been a constant target in the plans proposed to intensify vector control in interepidemic periods (44). Two studies have evaluated these points and showed that they influence the speed of spreading of dengue $(39,40)$.

Rain was positively associated or correlated with dengue epidemics in different regions of the country $(6,10,12,14,18,21,23)$. Temperature, another factor that influences various stages of Ae. aegypti development, has been correlated or associated with dengue epidemics in several studies $(12,16,20,24-26,28)$. At temperatures favorable to their life cycle, insects not only complete their development but do so more quickly, which can increase the vector's competence for arboviruses $(45,46)$. The present systematic review also showed three studies $(20,24,29)$ in which the relative humidity of the air was correlated or associated with the oviposition behavior of the mosquito populations studied, which consequently correlated to dengue epidemics in these regions.

Variables related to economic social factors played an important role in the dengue epidemics in the state of Amazonas (44), in the municipalities of Salvador (Bahia) (36) , Natal (Rio Grande do Norte) (22), Várzea Paulista (Sao Paulo) (33), Caraguatatuba (Sao Paulo) (41), São José do Rio Preto (Sao Paulo) (47), Osasco (Sao Paulo) (37), Araraquara (Sao Paulo) (35), Rio de Janeiro (Rio de Janeiro) (14), Itaboraí (Rio de Janeiro) (32), Vitória (Espirito Santo) (48), and in Brazil as a whole (36). It was observed that in all regions of Brazil, the socioeconomic factor was determining for the dengue epidemic. Some structural problems of the current health system continue to be positively associated with dengue epidemics, such as the number of field agents per property and the ratio of endemic agent supervisors to buildings, which is lower than initially proposed for the coverage of certain areas (21).

The association between the occurrence of dengue and the proportion of containers to store water at ground level was shown in one study (13). A similar result was seen in another study carried out in 2015 (after the 2014 water crisis) in the Southeast region, which showed a correlation between the same group of containers with the incidence of dengue (49). The population's behavior of retaining water in storage containers allows the development of immature forms of the Ae. aegypti, which were verified in several states in the Southeast and Northeast regions of the country (36).

The vectors Ae. aegypti and Ae. albopictus are commonly found inside homes and in properties close to homes, such as vacant lots and backyards (3). Studies in the Southeast region have shown that the proximity to parks, urban areas, and the number of neighbors, in addition to the proportion of the human population, are directly associated with the incidence of dengue $(14,20,26)$. Nevertheless, the authors of a study carried out in 2017, in the Greater ABC Paulista, argue that the presence of pollution from factories in industrial areas negatively correlates with the increase in the number of dengue cases (29).

Another reported difficulty is the number of pending actions in the vector control of dengue, as a high proportion of properties are closed or deny access to the endemic agents (15). In addition, it was found that the low coverage of the Family Health Program (15) and the insufficient coverage of the Municipal Health Center for individuals (50) were also considered risks for dengue epidemics.
Although we followed the recommendations of PRISMA, there is a possibility of publication bias, which may hinder generalizations of the results in the present study. Also, most of the studies were ecological type, so it is important to consider the possibility of ecological bias. The ecological studies presented different methodologies and analytical approaches, so this can be a problem for external validity and generalization. The quality assessment wasn't possible due to the lack of a specific and robust tool to evaluate ecological studies.

We hope that the information reported here can guide the understanding of the installation of epidemics in the country given the different problems related to the environment, infrastructure, meteorological and climatic characteristics, and the great Brazilian territorial extension. Another relevant aspect verified in the studies included in the present systematic review is the recommendation for the continuity of effective actions to control the vector in non-epidemic periods to avoid a subsequent epidemic. Studies that continuously investigate the factors associated with dengue epidemics should be encouraged. The endemic-epidemic character of the disease in Brazil, associated with the circulation of other arboviruses transmitted by $A$ e. aegypti, reinforce the need for comprehensive studies in different areas of knowledge for the improvement and the development of new strategies and/or tools for its control and prevention.

In conclusion, factors associated with dengue epidemics go beyond the health sector and reveal inequalities on social determinants of affected populations. The vector's ability to adapt to human-inhabited environments, the organization of geographic spaces in urban centers, people's cultural habits, the socioeconomic level of the population, changes in the population's behavior, social inequalities, social determinants of health, and the country's climate, among others, are factors that favor the risk of dengue epidemics. In the studies analyzed here there was an association between the variables "air pollution produced by the factory" and "wind speed" as an inhibitor of mosquito proliferation in some regions, which can reduce the occurrence of epidemics. Therefore, the development of a vaccine, the fight against the vector, the provision of adequate water, education actions targeting the population, the structuring of services to prevent and combat the vector, as well as measures for the early detection of cases are important in the control of the disease in Brazil.

Acknowledgements. The authors thank Mr. Gesner Xavier, the librarian from Universidade Federal de Minas Gerais, for his support during the definition of the descriptors and the search strategies.

Authors 'contributions. SCS, JMTB and DSB: conception and design of the study, data analysis. SCS, JMTB and DSB, MC and AEE: data interpretation and critical review of the manuscript. All authors revised and approved the final submitted version.

\section{Conflicts of interest. None declared.}

Disclaimer. Authors hold sole responsibility for the views expressed in the manuscript, which may not necessarily reflect the opinion or policy of the RPSP/PAJPH or the Pan American Health Organization (PAHO). 


\section{REFERENCES}

1. Osanai CH, Rosa APAT, Tang AT, Amaral RS, Passos ADC, Tauil PI. Surto de dengue em Boa Vista, Roraima. Rev Inst Med Trop S Paulo. 1983;25(1):53-4.

2. Mansho W. Estudo epidemiológico da dengue no período de 2000 a 2005 no Município de Guarulhos (SP) [master's thesis]. São Paulo: Faculdade de Medicina Veterinária e Zootecnia, Universidade de São Paulo; 2006.

3. Oliveira RL. Biologia e comportamento vetorial. In: Valle D, Pimenta DN, Cunha RV, editors. Dengue: teoria e prática. Rio de Janeiro: Fiocruz; 2015. p.75-92.

4. Focks DA. A review of entomological sampling methods and indicators for dengue vectors. Geneva: WHO; 2004. Available from: https:/ / apps.who.int/iris/handle/10665/68575. Accessed 03 Jul 2020

5. Teixeira TRA. Análise espacial e temporal da dengue no contexto socioambiental do município do Rio de Janeiro, 1996-2006 [master's thesis]. Rio de Janeiro: Escola Nacional de Saúde Pública Sérgio Arouca; 2009.

6. Valle D, Aguiar R, Pimenta D. Lançando luz sobre a dengue. Cienc Cult. 2015;67(3):4-5.

7. Brasil, Ministério da Saúde. Dengue: diagnóstico e manejo clínico adultos e criança. Brasília: Ministério da Saúde; 2016.

8. Teixeira MG, Costa MCN, Barreto ML, Mota E. Dengue e febre hemorrágica da dengue no Brasil: que tipo de pesquisas a sua tendência, vigilância e experiências de controle indicam ser necessárias? Cad Saude Publica. 2005;21(5):1307-131.

9. ABRASCO. Nota técnica sobre microcefalia e doenças vetoriais relacionadas ao Aedes aegypti: os perigos das abordagens com larvicidas e nebulizações químicas - fumacê. Rio de Janeiro: ABRASCO; 2016. Available from: https://www.abrasco.org.br/site/noticias/ institucional/nota-tecnica-sobre-microcefalia-e-doencas-vetoriais -relacionadas-ao-aedes-aegypti-os-perigos-das-abordagens-com -larvicidas-e-nebulizacoes-quimicas-fumace/15929/. Accessed 03 Jul 2020

10. Zeidler JD, Acosta POA, Barrêto PP, Cordeiro JS. Vírus dengue em larvas de Aedes aegypti e sua dinâmica de infestação, Roraima, Brasil. Rev Saúde Pública. 2008;42(6):986-91.

11. Nhantumbo EM, Pessanha JEM, Proietti FA. Ocorrência da dengue em área urbanas selecionadas e sua associação com indicadores entomológicos e de intervenção - Belo Horizonte, Brasil. Rev Med Minas Gerais. 2012;22(3):265-73.

12. Cardoso IM. Epidemiologia da dengue em Vitória, ES, 1995-2009 [master's thesis]. Vitória: Centro de Ciências da Saúde, Universidade Federal do Espírito Santo; 2010.

13. Arantes KM, Pereira BB. Análise da efetividade das ações de controle da dengue no munícipio de Uberlândia, MG a partir da matriz FPEEEA. J Health Biol Sci. 2017;5(4):326-36.

14. Teixeira TRA, Cruz OG. Spatial modeling of dengue and socioenvironmental indicators in the city of Rio de Janeiro, Brazil. Cad Saúde Pública. 2011;27(3):591-602.

15. Teixeira TRA, Medronho RA. Indicadores sócio demográficos e a epidemia de dengue em 2002 no Estado do Rio de Janeiro, Brasil. Cad Saúde Pública. 2008;24(9):2160-70.

16. Gomes RGS. Modelagem da incidência do dengue através de aspectos climáticos, entomológicos e sócio demográficos no município de João Pessoa, Paraíba [master's thesis]. João Pessoa: Universidade Federal da Paraíba; 2011.

17. Barbosa GL, Lourenço RW. Análise da distribuição espaço-temporal de dengue e da infestação larvária no munícipio Tupã, Estado de São Paulo. Rev Soc Bras Med Trop. 2010;43(2):145-51.

18. Souza SS, Silva IG, Silva HHG. Associação entre dengue, pluviosidade e densidade larvária de Aedes aegypti, no Estado de Goiás. Rev Soc Bras Med Trop. 2010;43(2):152-5.

19. Melo MSS, Barreto, FR, Costa MCN, Morato VC, Texeira MG. Progressão da circulação do vírus do dengue no Estado da Bahia, 1994-2000. Rev Soc Bras Med Trop. 2010;43(2):139-44.

20. Oliveira MA. Condicionantes socioambientais urbanos associados à ocorrência de Dengue no munícipio de Araraquara [dissertation]. São Paulo: Faculdade de Saúde Pública, Universidade de São Paulo; 2012.

21. Castro DB, Sampaio VS, Albuquerque BC, Pinto RC, Sadahiro M, Passos RA, Costa CF, Braga JU. Dengue epidemic typology and risk factors for extensive epidemic in Amazonas state, Brazil, 2010-2011. BMC Public Health. 2018;18(1):356.

22. Barbosa IR, Silva LP. Influence of environmental and social determinants in spatial distribution of Dengue Fever in Natal, RN-Brazil. Rev Ciência Plural. 2015;1(3):62-75.

23. Monteiro ESC, Coelho ME, Cunha IS, Cavalcante MAS, Carvalho FAA. Aspectos epidemiológicos e vetoriais da dengue na cidade de Teresina, Piauí - Brasil, 2002 a 2006. Epidemiol Serv Saúde. 2009;18(4):365-74.

24. Filho-Correia WLF. Influence of meteorological variables on dengue incidence in the municipality of Arapiraca, Alagoas, Brazil. Rev Soc Bras Med Trop. 2017;50(3):309-14.

25. Scandar SAS, Vieira P, Cardoso RP Jr, Silva RA, Papa M, Sallum MAM. Dengue em São José do Rio Preto, Estado de São Paulo, Brasil, 1990 a 2005: fatores entomológicos, ambientais e socioeconômicos. Bepa. 2010;7(81):4-16.

26. Varejão TM. Análise espacial do padrão de introdução e disseminação da dengue nos municípios do Espírito Santo [master's thesis] Vitória: Centro de Ciências da Saúde, Universidade Federal do Espírito Santo; 2013.

27. Baia SSV. Estudo das relações entre as variáveis ambientais e a incidência de dengue nos municípios de Santarém, Tucuruí e Bragança (Pará), no período Janeiro de 2007 a julho de 2011 [master's thesis]. Belém: Núcleo de Medicina Tropical, Universidade Federal do Pará; 2014

28. Araujo RV, Albertini MR, Costa-da-Silva AL, Suesdek L, Franceschi NC, Bastos NM, Katz G, Cardoso VA, Castro BC, Capurro ML, Allegro VL. São Paulo urban heat islands have a higher incidence of dengue than other urban areas. Braz J Infect Dis. 2015;19(2):146-55.

29. Carneiro MAF, Alves BCA, Gehrke FS, Domingues JN, Sá N, Paixão S, Figueiredo J, Ferreira A, Almeida C, Machi A, Savóia E, Nascimento V, Fonseca F. Environmental factors can influence dengue reported cases. Rev Assoc Med Bras. 2017;63(11):957-61.

30. Rodrigues NCP, Lino VTS, Daumas Rp, Andrade MNKN. Temporal and Spatial Evolution of Dengue Incidence in Brazil, 2001-2012. PLos ONE. 2016;11(11):e0165945.

31. Arantes KM. Análise da efetividade das ações de controle da dengue no munícipio de Uberlândia, MG a partir da matriz FPEEEA [master's thesis]. Uberlândia: Instituto de Geografia, Universidade Federal de Uberlândia; 2017.

32. Vargas WP, Kawa H, Sabroza PC, Soares VB, Honório NA. Association among house infestation index, dengue incidence and sociodemographic indicators: surveillance using geographic information system. BMC Public Health. 2015;15(1):746.

33. Farinelli EC. Dengue em município do interior paulista: áreas de risco e relação com variáveis socioeconômicas, demográficas e ambientais [master's thesis]. São Paulo: Faculdade de Saúde Pública, Universidade de São Paulo; 2014.

34. Martins MMF, Almeida AMFL, Fernandes NDR, Silva LS, Lima TB, Orric AS, Ribeiro HL Jr. Análise dos aspectos epidemiológicos da dengue na microrregião de saúde de Salvador, Bahia, no período de 2007 a 2014. Espaç Saúde. 2015;16(4):64-73.

35. Ferreira AC. Epidemiologia espacial da Dengue em Araraquara, São Paulo, 2008 a 2015 [dissertation]. Araraquara: Faculdade de Ciências Farmacêuticas.

36. Calvalcanti LPG, Oliveira RMAB, Alencar CH. Changes in infestation sites of female Aedes aegypti in Northeast Brazil. Rev Soc Bras Med Trop. 2016;49(4):498-501.

37. Pinto FKA. Análise espacial da distribuição dos casos de dengue no munícipio de Osasco de 2007 a 2013 [master's thesis. São Paulo: Faculdade de Medicina Veterinária e Zootecnia, Universidade de São Paulo; 2016.

38. Silva CM. Estudo epidemiológico da dengue no município de São Paulo [master's thesis]. São Paulo: Universidade de São Paulo; 2016.

39. Malavasi HG. Análise espacial da epidemia de dengue em Campinas/SP no ano de 2007 [master's thesis]. Campinas: Faculdade de Ciências Médicas, Universidade Estadual de Campinas; 2011.

40. Johansen IC. Urbanização e saúde da população: o caso da dengue em Caraguatatuba (SP) [master's thesis]. Campinas: Instituto de 
Filosofia e Ciências Humanas, Universidade Estadual de Campinas; 2014.

41. Duque JEL, Silva RV, Kuwabara EF, Navarro-Silva MA. Dengue no Estado do Paraná, Brasil: distribuição temporal e espacial no período 1995-2007. Rev Salud UIS. 2010;42(2):113-22.

42. Chiaravalloti-Neto F, Pereira M, Fávaro EA, Dibo MR, Mondini A, Rodrigues-Junior AL, Chierotti AP, Nogueira ML. Assessment of the relationship between entomologic indicators of Aedes aegypti and the epidemic occurrence of dengue virus 3 in a susceptible population, São José do Rio Preto, São Paulo, Brazil. Acta Trop. 2015;142:167-77.

43. Oliveira RL. Transmissão Vetorial. In: Valle D, Pimenta DN, Cunha RV, editors. Dengue: teoria e prática. Rio de Janeiro: Fiocruz; 2016. p.127-46.

44. Brasil, Ministério da Saúde. Diretrizes nacionais para prevenção e controle de epidemias de dengue. Brasília: Ministério da Saúde; 2009.

45. Muturi EJ, M. Blackshear, A. Montgomery. Temperature and density-dependent effects of larval environment on Aedes aegypti competence for an alphavirus. J Vector Ecol. 2012;37:154-61.

46. Marinho RA, Beserra EB, Bezerra-Gusmão MA, Porto Vde S, Olinda RA, Dos Santos CA. Effects of temperature on the life cycle, expansion, and dispersion of Aedes aegypti (Diptera: Culicidae) in three cities in Paraiba, Brazil. J Vector Ecol. 2016;41(1):1-10.

47. Mondini A, Chiaravallti-Neto F. Variáveis socioeconômicas e a transmissão de dengue. Rev Saúde Pública. 2007;41(6):923-30

48. Vicente CR, Herbinger KH, Cerutti C Jr, Romano CM, Cabidelle ASA, Fröschl G. Determination of clusters and factors associated with dengue dispersion during the first epidemic related to Dengue virus serotype 4 in Vitoria, Brazil. PLoS ONE. 2017;12(4):e0175432.

49. Marengo J, Nobre CA, Seluchi M, Cuartas A, Alves L, Mendiondo E, Obregón G, Sampaio G. A seca e a crise hídrica de 2014-2015 em São Paulo. Rev USP. 2015;106:31-44.

50. Costa JV, Donalisio MR, Silveira LVA. Spatial distribution of dengue incidence and socio-environmental conditions in Campinas, São Paulo State, Brazil, 2007. Cad Saúde Pública. 2013;29(8):1522-32.

Manuscript received on 24 November 2020; revised version accepted for publication on 30 April 2021.

\section{Factores asociados a la aparición de epidemias de dengue en Brasil: revisión sistemática}

RESUMEN Objetivo. Determinar y describir de manera amplia los factores relacionados con la aparición de epidemias de dengue en Brasil.

Métodos. Se llevó a cabo una revisión sistemática de los estudios publicados en MEDLINE, LILACS, PubMed, Cochrane, BVS, Web of Science, Scopus y en bases de datos de tesis y trabajos de final de grado con los descriptores catalogados en DeCS y MeSH sobre dengue y factores asociados con la aparición de epidemias publicados entre 2008 y 2018.

Resultados. Se seleccionaron 35 estudios llevados a cabo en Brasil. Las epidemias registradas en el país se asociaron o se relacionaron con diversos factores, como el medioambiente, las condiciones socioeconómicas, el clima y aspectos relacionados con el vector, entre otros.

Conclusiones. Las epidemias de dengue son complejas y multifactoriales. Se constató que la continuidad de las medidas de control de vectores es pertinente para la reducción de Aedes aegypti, así como para el control de la enfermedad. Para contener la propagación de la enfermedad son necesarias medidas eficaces en todos los sectores, como la salud, la educación, la economía, la población, las empresas y el gobierno. Las medidas de detección temprana de casos de la enfermedad pueden prevenir nuevos brotes de epidemias.

Palabras clave Dengue; factores de riesgo; epidemias; Brasil. 


\section{Fatores associados à ocorrência de epidemias de dengue no Brasil: uma revisão sistemática}

RESUMO Objetivo. Identificar e descrever, de forma geral, os fatores relacionados à ocorrência de epidemias de dengue no Brasil.

Métodos. Revisão sistemática de estudos publicados entre 2008 e 2018 nas bases de dados MEDLINE, LILACS, PubMed, Cochrane, BVS, Web of Science e Scopus e em bancos de teses e dissertações, com o uso de descritores de dengue e de fatores associados à ocorrência de epidemias catalogados no portal DeCS/ $\mathrm{MeSH}$.

Resultados. Trinta e cinco estudos realizados no Brasil foram selecionados. As epidemias registradas no país foram associadas e/ou correlacionadas a vários fatores como meio ambiente, condições socioeconômicas e climáticas, e aspectos relacionados ao vetor, entre outros.

Conclusões. As epidemias de dengue são complexas e multifatoriais. Observou-se que ações contínuas de controle vetorial são essenciais para a redução da população de Aedes aegypti e o controle da doença. Para conter a propagação da dengue são necessárias medidas multissetoriais eficazes, abrangendo saúde, educação, economia, população, negócios e governo. As ações visando à detecção precoce de casos da doença contribuem para prevenir novos surtos epidêmicos.

Palavras-chave Dengue; fatores de risco; epidemias; Brasil. 